\title{
The spread of parasitic dipteran insects of cattle
}

\author{
Katiukha S. \\ Experimental Station of Epizootology of the Institute of Veterinary Medicine of NAAS, 16/18 Kniazia \\ Volodymyra Str., R ivne, 33028, Ukraine; e-mail: katyuha.71@ukr.net
}

\begin{abstract}
Goal. To study the North-Western region of Ukraine as to the distribution and flight periods of blood-sucking dipteran insects, zoophilic flies, and botflies to protect the cattle from their attacks. Methods. Field, parasitological, laboratory, and calculation. Results. 20 species of gadfly parasite on cattle (fam. Tabanidae), which belong to the genera: Hybomitra, Chrysops, Tabanus, Haematopota, Atylotus, and Heptatoma. The flight and attack on the animals occurs from May to September, and the greatest number in July and the first half of August. 35 species of mosquitoes (fam. Culicidae) are discovered. The most common of them belong to the genera: Aedes, Anopheles, and Culex. They traced 2 increase in their amount depending on the characteristics of the season: spring (May - June) and summer (July). There are fixed 33 species of midges (fam. Simuliidae) on the territory. The genera Schoenbaueria, Simulium, and Boophthora are the dominant ones. Seasonal dynamics of attacks is characterized by two periods of increased activity of the midges spring (May) and summer (late July - early August). Fauna of malanders (fam. Ceratopogonidae) encounters 15 species. Massive attack on the animals is observed in May-June and in early August. 10 types of zoophilic flies (fam. Muscidae) are fixed. The most common — licking (M. domestica, M. autumnalis, M. larvipara), and blood-sucking (S. calcitrans, $H$. stimulans, $H$. atripalis). They attack from late April to October, the largest number - from the end of June to September. All identified gadflies (fam. Hypodermatidae) belong to the same species - Hipoderma bovis. They are active mostly in July - August. Conclusions. Species composition, number, and timing of flight of blood-sucking dipteran insects, zoophilic flies and gadflies in the climatic zones of North-West region vary. Maximum species diversity was in the area of Polissia: gadflies 20 , mosquitoes - 35, midges - 33, malanders - 15, zoophilic flies - 10, gadflies -1 . The total flight period lasts from late April to October, the maximum activity is fixed in the period from May to September. Measures for the protection of cattle against harmful dipteran insects in the area of Polissia and Forest-Steppe should be taken in May and September.
\end{abstract}

Key words: gadflies, mosquitoes, midges, flies, botflies, species diversity, numerous activities. DOI: https://doi.org/10.31073/agrovisnyk202007-07

In the system of veterinary and sanitary measures in places where animals are kept, the control of harmful insects is important. Particularly dangerous for cattle are gnats (horseflys, mosquitoes, black-flies, bitingflys), zoophilic flies and gadfly, which lead to a decrease in their productivity and intoxication of the body [1-5]. In addition, ectoparasites are intermediate hosts and vectors of infectious and invasive diseases [6]. The presence of, for example, flies on livestock farms causes bacterial contamination of milk, which reduces its quality $[7,8]$. Among the disgust are especially dangerous midges, which in a mass attack cause not only disease - simuliidotoxicosis, but also the death of animals [9]. It is generally accepted that in the conditions of mass spread of disgust livestock becomes unprofitable due to losses in weight gain of young animals by 25$40 \%$ and reduction of milk yield of cows by more than $40 \%$ [10].

Particularly significant economic losses in the farms of the North-Western region of Ukraine, where there is a favorable environment for the formation foci of mass reproduction and attack of geese and other insects [11]. From ectoparasites animals are damaged throughout the year, but especially in spring and summer.

To successfully control pests, it is necessary to know in detail the entomological situation in a particular area, region, zone - a group of ectoparasites, the area in which they are most common and the factors that contribute to or inhibit their development. Knowledge of the start and end dates of the flight of gnats, flies and gnats is the biological basis for measures to protect cattle from the attack of adults of these insects in the summer. Thus, effective control of harmful dipterans insects is possible only on the basis of studying their fauna, biology and ecology in the specific conditions of a particular area.

The purpose of the research is to study the distribution and timing flight of blood-sucking dipterans insects, zoophilic flies and gadfly in the North-Western region of Ukraine to carry out measures to protect cattle from their attack.

Materials and methods of research. The work was performed in the field in the North-Western region of Ukraine. In house processing of the material, including identification of collected insects, analysis of own and literature data, was performed on the basis of the Experimental Station of Epizootology of the IVM of NAAS (Rivne).

Flight periods and the dynamics of the number of insects of the gnus complex, zoophilic flies and gadfly were studied by conducting systematic surveys throughout the summer season. Collecting horseflys, mosquitoes, black-flies, bitingflys, zoophilic flies, gadfly was carried out by catching an entomological net with removable bags. In addition to net counts, the activity and dynamics of the number of adult insects were 
determined by a digital camera, which was used to record their attack on all parts of the animal's body [12]. The number of dipterans insects was counted on a computer monitor with a sequential view of the frames in an enlarged format. Accounts were performed during the hours of maximum daily activity of insects, during the entire flight period, followed by calculation of averages. In laboratory conditions determined the species of imago insects and performed statistical processing of the obtained data.

Research results. The study area is located in the extreme northwest of Ukraine. Most of it is located in the Polissya lowland, the rest - on the Volyn upland. The territory covers Volyn and Rivne regions, with a total area of 40.3 thousand $\mathrm{km}^{2}$. Flatness, the predominance of precipitation over evaporation leads to waterlogging of a large area. The soils of most of the district are low-fertile, sod-podzolic. There are significant water resources, dense river network, many lakes. In terms of forest resources, the district is second only to the Carpathian region. Forests cover more than $40 \%$ of its territory.

The leading branch of animal husbandry in the Northwest is cattle breeding. In Polissya it has a dairy-meat direction, in forest-steppe areas - meat-dairy. Success in this area depends not only on the forms of management, quality feeding, but also on the health of livestock, including the prevention and treatment of diseases caused by dicotyledonous ectoparasites, which are particularly common in the region (Table 1).

\section{Distribution of gnus, flies and gadfly parasitizing on cattle in the North-Western region of Ukraine}

\begin{tabular}{|c|c|c|}
\hline Insects & Polissya & Forest-steppe \\
\hline \multicolumn{3}{|c|}{ Gnus } \\
\hline Horseflys (genus Tabanidae) & 20 & 15 \\
\hline Mosquitoes (genus Culicidae) & 35 & 28 \\
\hline Black-flies (genus Simuliidae) & 33 & 27 \\
\hline Bitingflys (genus Ceratopogonidae) & 15 & 10 \\
\hline \multicolumn{3}{|c|}{ Flies } \\
\hline Zoophilic flies (genus Muscidae) & 10 & 10 \\
\hline \multicolumn{3}{|c|}{ Gadfly } \\
\hline Subcutaneous gadfly (genus Hypodermatidae) & 1 & 1 \\
\hline
\end{tabular}

Among the blood-sucking dipterans insects (gnus) - horseflys (genus Tabanidae) in the North-Western region are represented by 20 species from 6 genera: Hybomitra, Chrysops, Tabanus, Haematopota, Atylotus, Heptatoma. Cattle are most often attacked by H. pluvialis, T. autumnalis, T. bromius, T. rusticus, T. glaucopis, T. bovinus, C. relictus, C. caecutiens, and others. Departure and attack on animals is observed from May to September, and their greatest number - in July and the first half of August (table 2). According to observations, the daily activity of the attack of these insects is different. In mid-May, horseflys begin to fly and attack from 10 o'clock and the maximum activity occurs at $13-15$ o'clock in the afternoon, in June - July they are active from $6-7$ hours, and from $9-10$ o'clock the summer becomes massive, reaching a peak at $13-14$ hours. In August, horseflys are most active at $2-4$ p.m. In September, after 4 pm, there is usually a sharp decrease in the activity of the attack of bloodsuckers.

\section{Terms of flight of gnus, zoophilic flies, gadfly and measures to protect cattle from their attack}

\begin{tabular}{|c|c|c|c|c|c|c|c|}
\hline \multirow{3}{*}{ Insects } & \multicolumn{7}{|c|}{ Insect activity by decades } \\
\hline & 를 & $\sum^{\frac{\pi}{2}}$ & 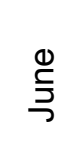 & $\frac{\lambda}{3}$ & $\begin{array}{l}\overline{\mathrm{w}} \\
\frac{\mathrm{g}}{\mathrm{g}}\end{array}$ & 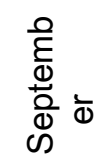 & $\begin{array}{l}\bar{\Phi} \\
\stackrel{0}{0} \\
\stackrel{0}{0} \\
0\end{array}$ \\
\hline & & & & & & & \\
\hline $\begin{array}{l}\text { Horseflys } \\
\text { (genus Tabanidae) }\end{array}$ & & & & & & & \\
\hline
\end{tabular}




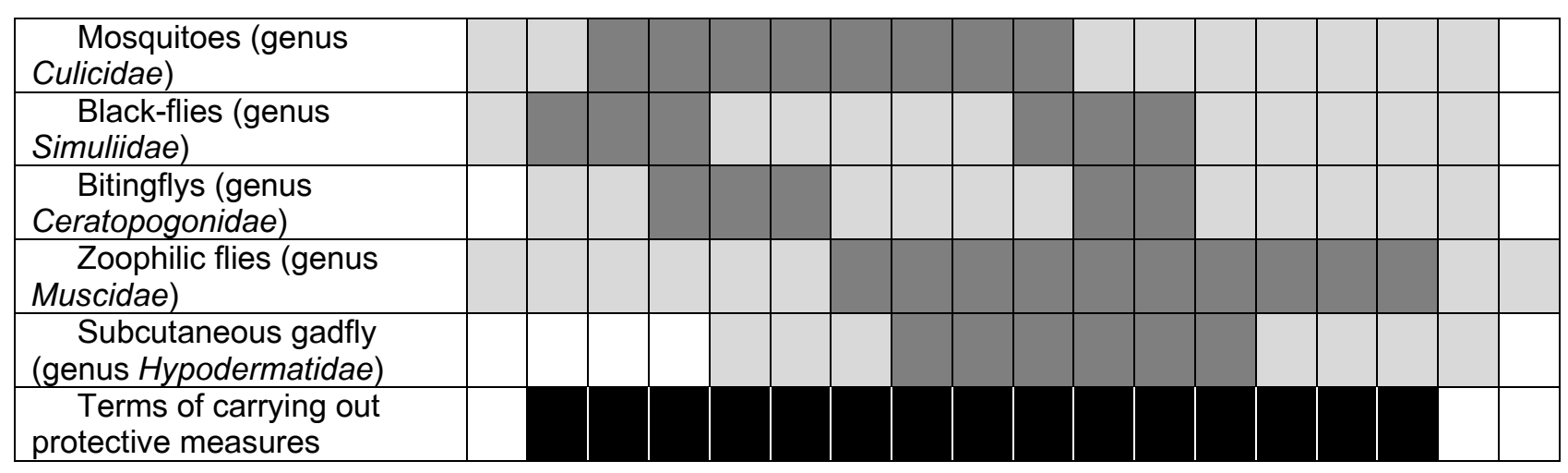

In the area of western Polissya, 35 species of mosquitoes (genus Culicidae) parasitize on cattle, and 28 species in the forest-steppe regions. In the region, these are the main components of disgust. The most numerous were mosquitoes of the genera Aedes, Anopheles, Culex. The mass (over 95\% of the number of all species) include: $A$. vexans, $A$. punctor, $A$. cantans, $A$. communis, $A$. excrucians, $A$. dorsalis, $A$. flaviscens, A. cinereus, An. maculipennis, C. pipiens. The breeding of the first generation of kulicide begins in late April - early May. Depending on the peculiarities of the season, there are two rises in the number of mosquitoes: spring (May - June) and summer (July). The daily rhythm of kulicide activity is also characterized by two rises: morning $(7-10 \mathrm{~h})$ and evening $(18-20 \mathrm{~h})$.

Among the gnus are especially dangerous black-flies (genus Simuliidae), which in a mass attack cause not only disease - simuliidotoxicosis, but also the death of animals. In the conditions of western Polissya 33 species of simuliids are widespread, and in the forest-steppe zone -27 species. Adult flight is observed throughout the warm period, from April to October. However, the seasonal dynamics of black-flies attack is characterized by two well-marked periods of increased activity - spring (May) and summer (late July - early August). The dominant species of bloodsuckers of the spring generation are members of the genera Schoenbaueria, Boophthora and Simulium (over 90\%), summer - Boophthora and the group Morsitans (over $80 \%)$. The circadian rhythm of simuliid activity is characterized by two peaks of attack activity - morning (7 $-10 \mathrm{~h})$ and evening $(18-21 \mathrm{~h})$. Among the environmental factors that determine the circadian rhythm of black-flies activity, it should be noted the temperature, light and sometimes wind speed.

In the forest zone of the region, the fauna of bitingflys (genus Ceratopogonidae) is represented by 15 species, and in the steppe - 10 species belonging to the genus Culicoides. In western Polissya, their attack on animals is observed in the first days of May with increasing intensity to the first - second decade of June. Then their number markedly decreases, although during the first - second decade of August it increases again. The circadian rhythm of bitingflys attack is characterized by morning and evening peaks of activity in the absence of seizures day and night.

Zoophilic flies that parasitize cattle are represented by 10 species. In the region, the most common are members of the family Muscidae, in particular, licking flies - M. domestica, M. autumnalis, M. larvipara, bloodsucking - S. calcitrans, $H$. stimulans, $H$. atripalis and others. Their species composition, as well as the number in different places of keeping animals, even in the same area are not constant. They attack from late April to October, and most of them - from late June to September. Flies are active throughout the day, but their particularly intense attack is observed at temperatures up to $26-30{ }^{\circ} \mathrm{C}$.

The gadfly (genus Hypodermatidae) are common in the region, all of which belong to 1 species of Hipoderma bovis. Causing hypodermatosis in cattle, they cause significant economic damage to livestock. In Polissya, gnats start flying and attacking in June, but they are most active in July - August. According to observations, in bad weather in June - July, the mass flight of gadfly begins later - in August - September. It was also found that most gadfly fly on sunny windless days from $10-11$ to $19-20$ hours.

\section{Conclusions}

The territory of the North-Western region of Ukraine is characterized by favorable conditions for the development and spread of blood-sucking dipterans insects, zoophilic flies and gadfly - parasites of cattle. Species composition, number and flight time of insects in natural and climatic zones vary. Their maximum species diversity is registered in the Polissya area: horseflys - 20, mosquitoes - 35, black-flies - 33, bitingflys -15 , zoophilic flies - 10, gadfly - 1. The total flight period lasts from late April to October, and their maximum activity - from May to September. In accordance with the general flight time and the maximum number of gnus, flies, gadfly, protective measures in the area of Polissya and forest-steppe must be carried out during May - September.

\section{References}

1. Yatusevich, A. I. et al. (Yatusevich A. I. (Ed.)) (2019). Arahnojentomoznye bolezni zhivotnyh [Arachnoentomosis diseases of animals]. Vitebsk: VSAVM. [In Belarusian]. 
2. Gavrichkin, A. A., Khlyzova, T. A., Fdorova, O. A. \& Sivkova, E. I. (2016). Zashhita sel'skohozjajstvennyh zhivotnyh ot krovososushhih dvukrylyh nasekomyh $v$ Tjumenskoj oblasti (obzor) [Protection of farm animals from blood-sucking dipterans insects in the Tyumen region (review)] Tauride Journal of Agricultural Science, 2(6), 3647. [In Ukrainian].

3. Vasilevich, F. I., Stasyukevich, S. I. \& Yatusevich, A. I. (2016). Ovodovye bolezni zhivotnyh i sovremennye mery borby s nimi [The gadfly diseases animal and modern control measures]. Moscow: Kolos. [In Russian].

4. Phasuk, J., Prabaripai, A. \& Chareonviriyaphap T. (2013). Seasonality and daily flight activity of stable flies (Diptera: Muscidae) on dairy farms in Saraburi Province, Thailand. Parasite, 20, 107-124. DOI:10.1051/parasite/2013016.

5. Wedincamp, J. \& Lance, A. (2016). Ectoparasites of White-Tailed Deer (Artiodactyla: Cervidae) in Southeastern Georgia, USA. Journal of Entomology Science, 51(2), 113-121. doi: 10.18474/JES15-27.1.

6. Mushynsky, A. \& Levitskaya, V. (2018). Krovosisni chlenistonogi jak perenosniki transmisivnih zahvorjuvan' tvarin [Blood-sucking arthropods as vectors of transmissible diseases of animals]. Agricultural science and education in the context of European integration '18: Mizhnarodna naukovo-praktichna konferencija (20-22 bereznja 2018) - International scientific-practical conference. Vol. 2 (pp. 66-68). Ternopil: Krok. [In Ukrainian].

7. Novikov, P. V. \& Safiullin, R. T. (2014). Sutochnaja aktivnost' muh v pomeshhenijah [Daily activity of flies indoors]. Theory and practice of parasitic animal diseases, 15, 202-204. [In Russian].

8. Woolley, C. (2013). Attack intensity of pest flies and the behavioral responses of pastured dairy cows. M.S. thesis. Ontario: University of Guelph.

9. Katyukha, S. M. (2018). Osoblivosti klinichnogo projavu simuliïdotoksikozu velikoï rogatoï hudobi v umovah Zahidnogo Polissja Ukraïni [Peculiarities of clinical manifestation of bovine simuladotoxicosis in the conditions of Western Polissya of Ukraine]. Veterinary biotechnology, 32, 39-44. [In Ukrainian].

10. Khlyzova, T. A., Fedorova, O. A. \& Sivkova, E. I. (2017). Patologicheskoe vozdejstvie sljuny krovososushhih dvukrylyh nasekomyh na organizm cheloveka i zhivotnyh (obzor) [The pathological effect of the saliva of blood-sucking diptera insects on the human body and animals (review)]. Bulletin of Orenburg State University, 7(207), 90-96. Orenburg: OGU. [In Russian].

11. Shevchenko, A. M. \& Slobodian, R. O. (2017). Study of spreading, dynamics of flying, attack and predominance of flies of the family Muscidae (Diptera, Insecta) in Cattle at livestock farms of Kyiv and Rivne regions of Ukraine. Journal of Entomology and Zoology Studies, 5, 349-355.

12. Katyukha, S. M. \& Shevchenko, A. M. (2012). Sposib obliku chisel'nosti krovosisnih dvokrilih komah na tvarini za dopomogoju cifrovoï fotokameri [Method of counting the number of blood-sucking two-winged insects on an animal using a digital camera]. Patent UA for utility model no 69220. MPK (2012): A01K67/00. From 25.04.2012. [In Ukrainian]. 